\title{
A LAW AND BEHAVIOURAL ECONOMICS ANALYSIS OF HIGH-COST LENDING IN NEW ZEALAND
}

\section{J McLanahan*}

The most interesting recent developments in economics have come from behavioural economics, which attempts to model how people will behave in real life situations. The insights offered by behavioural economics can also be applied to law. This article discusses law and behavioural economics generally, and then applies it to the New Zealand high-cost loan industry. The high-cost loan industry is responsible for a great deal of harm in New Zealand, and in 2019 Parliament passed sweeping amendments to the Credit Contracts and Consumer Finance Act 2003 to insulate consumers from that harm. Law and behavioural economics suggest alternative strategies to those amendments that can address the harms while retaining the benefits that high-cost loans can provide. This article designed an experimental survey to test one such strategy, and the results and implications for policy are discussed.

\section{INTRODUCTION}

Consider a 10,000-word article. Estimate the number of words whose second to last letter is "n"'.

Now estimate the number of words which end with "-ing".

Most people would have estimated that there are a far greater number of words ending with "-ing" than those which have " $n$ " as the penultimate letter, despite the former being a subset of the latter. ${ }^{1}$

This logical error is due to the human brain relying on the easy availability of words organized in its memory that end in "-ing", substituting that ease for a more rigorous analysis. Psychologists

* This article is dedicated to the memory of Hamish McIntosh (1967-2020), a true friend and exceptional barrister, for his encouragement and guidance throughout my time at law school.

I would like to thank Paul Scott from the Victoria University of Wellington School of Law, as well as Dr Anne Macaskill and Rana Asgarova, School of Psychology, for their generosity with their time and thoughtful insights in shaping this article.

1 This article is 10,000 words: 360 words end in "-ing", and 1,163 words have the second to last letter of "n", including "second", "end" and "and". 
Tversky and Kahneman labelled this reliance on the ease of memory search as the "availability heuristic", one of numerous mental rules of thumb which lead to predictable biases and systematic errors in decision-making. ${ }^{2}$

Another common mental rule of thumb is the "optimism bias". Economist Thaler would ask his MBA students at the commencement of his class where along the distribution of grades their own future performance would lie. Typically, fewer than five per cent of his students would predict their grade to be below the median. ${ }^{3}$ Since, by definition, 50 per cent of students would fall below the median, this demonstrates a systematic irrational level of overconfidence in their abilities or optimism for their future performance.

These examples are part of behavioural economics, which challenges neoclassical economic assumptions (such as a stable set of preferences, the ability to process information and optimise decision-making) at the heart of the economic analysis of law. Behavioural economics is particularly relevant to contract law, the basis of which relies on the debatable assumption of rational people maximizing their self-interest. Where behavioural economics shows deviations from outcomes predicted by traditional assumptions, such insights should be incorporated into relevant legal policy to enhance its effectiveness. ${ }^{4}$

This article examines the application of behavioural economics to consumer credit contracts, specifically in relation to high-cost lending. ${ }^{5}$ The interest and fees of high-cost loans exceed that of traditional bank loans and the combined total of such interest and fees can be multiple times the original principal. While some high-cost borrowing is rational under traditional economic theory, much of it is best explained by behavioural economics. As such, this article uses a behavioural economics lens to review the current law and the effectiveness of the Credit Contracts Legislation Amendment Act 2019 (2019 Amendments) in strengthening consumer protections, and proposes the inclusion of alternative strategies to better address the harm caused by high-cost lending.

The article begins with traditional neoclassical assumptions and contrasts that with behavioural economics (Part II), followed by an overview of New Zealand's consumer lending industry and the government's recent legislative response to high-cost loans (Part III). Neoclassical and behavioural economic explanations for high-cost loans are explored in Part IV, the ramifications of the government's recent response, and an alternative response (namely debiasing which is based on behavioural economic principles), are in Parts V and VI respectively. Then, as outlined in Parts VII

2 Daniel Kahneman Thinking Fast and Slow (online ed, Farrar, Strauss and Giroux, New York, 2011) at 7.

3 Richard Thaler and Cass Sunstein Nudge: Improving Decisions about Health, Wealth, and Happiness (Penguin Books, New York, 2008) at 31.

4 Christine Jolls and Cass Sunstein "Debiasing Through Law" (2006) 35 JLS 199 at 200.

5 Sometimes referred to as "predatory lending" in the popular press. 
and VIII, an empirical study was undertaken to test the efficacy of debiasing strategies on high-cost lending. Finally, the potential benefits of using debiasing strategies to augment the current legislative approach are discussed in Part IX.

\section{LAW AND BEHAVIOURAL ECONOMICS}

Economic theory of contract law rests on the rational choice model which posits that purely rational people, the homo economicus, analyse transactions in terms of maximizing their utility. ${ }^{6}$ They do this from a stable set of preferences, which is defined broadly to incorporate emotion. ${ }^{7}$ Under the rational choice model, homo economicus make decisions with an optimal amount of information, utilising all information whose benefits outweighs the acquisition costs. ${ }^{8}$ For decisions made under uncertainty or across multiple time periods, the costs and benefits are weighted by probability and rationally discounted over time. Further, according to Bar-Gill: ${ }^{9}$

Modern, neoclassical economics recognizes that even perfectly competitive markets can fail, because of externalities and asymmetric information. Behavioural economics adds a third cause for market failure; misperception and bias.

This has been borne out in recent decades as economists and psychologists began to question whether neoclassical assumptions hold in the real world, as various experiments demonstrate systematic behaviour that the rational choice model could not explain. ${ }^{10}$ For example, the traditional assumption of a stable set of preferences was undermined by Thaler's experiments, which showed that people valued the same item differently depending on whether they owned it. The experiments demonstrated that people will demand a higher price to sell something they own, than to buy the same good if they do not own it. ${ }^{11}$ This result is contrary to the rational choice model which states that the

6 Marieke Bos, Susan Payne Carter and Paise Marta Skiba "Balancing act: new evidence and a discussion of the theory on the rationality and behavioural anomalies of choice in credit markets" in Joseph Teitelbaum (ed) Research Handbook on Behavioural Law and Economics (Edward Elgar Publishing Limited, Cheltenham, 2018) 101 at 102 .

7 For example, one might prefer goods in pretty wrapping paper to the same goods in a brown paper bag: Richard Posner "Rational Choice, Behavioural Economics, and the Law" (1998) 50 Stan L Rev 1551 at 1553 1554.

8 Christine Jolls, Cass Sunstein, Richard Thaler "A Behavioral Approach to Law and Economics" (1998) 50 Stan L Rev 1471 at 1473 and 1476.

9 Oren Bar-Gill Seduction by Contract (Oxford University Press, Oxford, 2012) at 16.

10 Thaler and Sunstein, above n 3, at 31; Cass Sunstein "Nudges.gov: Behaviorally Informed Regulation" in Eyal Zamir and Doron Teichman (eds) The Oxford Handbook of Behavioral Economics and the Law (Oxford University Press, Oxford, 2014) 719 at 719-720.

11 Daniel Kahneman, Jack Knetsch, and Richard Thaler "Anomalies: The Endowment Effect, Loss Aversion, and Status Quo Bias" (1991) J Econ Perspect 5(1) 193 at 194-197; and Daniel Kahneman, Jack Knetsch, and 
price of the good should be the same, regardless of initial ownership. Experiments have also shown the power of framing, that different ways of presenting the same information can yield different results. For instance, people's purchase decisions change depending on whether cold cuts are labelled as 90 per cent fat-free instead of 10 per cent fat, despite the obvious converse of the information presented. ${ }^{12}$ Further, under rational choice theory, when confronted with a variety of options, people will pick the option with the greatest benefits. However, it has been repeatedly shown that if the options include a default selection, that default is "chosen" at a significantly greater rate than rational theory can explain. ${ }^{13}$

Such irrational biases have policy implications. For example, the "default emphasis" has changed government policies on the structuring of retirement savings accounts in various countries, including in New Zealand, where the government recognises the importance of, and thoroughly reviews, defaults in KiwiSaver plans. ${ }^{14}$ One Danish study suggests that default policies can have a larger impact on retirement savings than economically relevant policies, such as the tax treatment of those savings. ${ }^{15}$ This completely contradicts the rational choice model.

While rational choice proponents have accepted that the model is not a perfect representation of the world, they still maintain that any variance in behaviour would be random and thus cancel out in aggregate. ${ }^{16}$ However, as the above experiments show, this is not the case as "human behaviour differs in systematic ways from that predicted by the standard economic model". ${ }^{17}$ Behavioural economics explains these systematic deviations from neoclassical theory through bounded rationality.

\section{A Bounded Rationality}

A critical underpinning of neoclassical economic theory is unbounded rationality, which attributes to humans a thoroughly sound judgement and decision-making capability. ${ }^{18}$ As an alternative, Simon

Richard Thaler "Experimental Tests of the Endowment Effect and the Coase Theorem" (1990) J Pol Econ 98 1325 at $1329-1336$

12 Matteo Godi "Beyond Nudging: Debiasing Consumers Through Mixed Framing" (2019) 128 Yale LJ 2034 at 2041; and Kahneman, above n 2, at 88.

13 Thaler and Sunstein, above n 3, at 85-89.

14 Ministry of Business, Innovation and Employment Review of the KiwiSaver Default Provider Arrangements (Discussion Paper, August 2019) at 7-12.

15 Raj Chetty and others "Active vs. Passive Decisions and Crowd-Out in Retirement Savings Accounts: Evidence from Denmark" (2014) 129 Q J Econ 1141 at 1215-1216.

16 Richard Posner Economic Analysis of Law (9th ed, Wolters Kluwer Law \& Business, New York 2014) at s 1.4; and Bar-Gill, above n 9, at 9.

17 Jolls, Sunstein and Thaler, above n 8, at 1477.

18 Herbert Simon "A Behavioral Model of Rational Choice" (1955) 69 Q J Econ 99 at 99. 
suggested a more realistic approach is "bounded rationality", ${ }^{19}$ based on "rational behaviour that is compatible with the access to information and computational capacities" that people possess, in realistic environments. ${ }^{20}$ Bounded rationality recognises that limited cognitive abilities, such as limited information processing, result in an "incomplete and inaccurate knowledge about the consequences of actions" 21 and necessitates the simplification of the real world. ${ }^{22}$ These simplifications, as discussed below, depart from the unbounded rationality of traditional theory and result in judgement errors. ${ }^{23}$ Such errors occur when "actual judgments show systematic departures from models of unbiased forecasts" due to both heuristics and biases. ${ }^{24}$

\section{Heuristics}

Heuristics are mental shortcuts on which people rely to "reduce the complex tasks of assessing probabilities and predicting values to simpler judgmental operations." 25 An example: "If it takes 5 machines 5 minutes to make 5 widgets, how long would it take 100 machines to make 100 widgets?"26

The answer which immediately leaps to mind is 100 minutes. This answer, as Kahneman highlights for a slightly different problem, is "intuitive, appealing, and wrong." 27 The mind sees an obvious shortcut and takes it, even though the math, if done directly, is straightforward. The actual answer is five minutes. ${ }^{28}$

While the above simple mathematical example might be dismissed as a cognitive quirk, ${ }^{29}$ heuristics can be far-reaching and systematic. ${ }^{30}$ The most significant example of which is "anchoring". People who are shown a number, then asked to estimate a value, will move their estimate closer to the

19 At 101 .

20 Simon, above n 18, at 99.

21 Herbert Simon An Empirically Based Microeconomics (Cambridge University Press, Cambridge, 1997) at 17; and Godi, above n 12, at 2041-2042.

22 Simon, above n 18, at 114 .

23 Jolls and Sunstein, above n 4, at 203.

24 Jolls, Sunstein and Thaler, above n 8, at 1477.

25 Amos Tversky and Daniel Kahneman "Judgment under Uncertainty: Heuristics and Biases" (1974) 185 Science 1124 at 1124 .

26 Kahneman, above n 2, at 44 .

27 At 44 .

28 Each machine takes five minutes to make one widget, so 100 machines can make 100 widgets in five minutes.

29 Posner, above n 16, at s 1.4

30 Richard Thaler Misbehaving: The Making of Behavioral Economics (WW Norton and Company, New York, 2015) at 23-24. 
number shown. That number anchors their estimates, even if it has nothing to do with the value being estimated. This effect is large and measurable. In one experiment where subjects were asked to estimate the height of redwood trees, those that had been previously shown an unrealistically high anchor number gave an answer triple the height of that estimated by those shown an unrealistically low anchor. ${ }^{31}$ Similar results are replicated in tests involving real-estate agents and MBA students who were asked to estimate house values, having seen both low and high anchors. ${ }^{32}$ Interestingly, this effect was apparent even when subjects were explicitly shown the anchor number generated randomly by, for example, using a roulette wheel. ${ }^{33}$ Simply being shown a number, however irrelevant, systematically changes the estimates people produce toward the anchoring number.

Another powerful heuristic is "availability". Tversky and Kahneman showed that people will judge frequency by "the ease with which instances or occurrences can be brought to mind." ${ }^{34}$ When frequency (and resulting probability) is estimated, "instances of the class will be retrieved from memory, and if retrieval is easy and fluent, the category will be judged to be large." 35 For instance, when asked whether the letter " $r$ " is more likely to be the first or third letter of a word, it is easier to come up with words that start with "r" (such as road), than with "r" as the third letter (such as car), which exaggerates the perceived frequency. ${ }^{36}$ In fact, " $r$ ", and a number of other consonants (such as "k", "l", "n", "v") are more frequent as a third letter in a word than the first. ${ }^{37}$

This reliance on availability impacts decision-making in several ways. First, people "assess the likelihood of risks by asking how readily examples come to mind." If a relevant example is readily

31 Kahneman, above $\mathrm{n}$ 2, at 123. One group of subjects was asked whether the height of the tallest redwood trees was more or less than 1,200 feet, while another was asked if the height was more or less than 180 feet. Both groups were then asked to give their best guess as to the height. The first group produced a mean estimate of 844 feet, while the mean estimate of the second was 282 feet. This is a clear, systematic departure from an unbiased estimate.

32 Gregory Northcraft and Margaret Neale "Experts, Amateurs and Real Estate: An Anchoring-and-Adjustment Perspective on Property Pricing Decisions" (1987) 39(1) Organ Behav Hum Decis Process 84 at 87-96. Real estate agents were separately asked to estimate the value of a house for sale at the time. The actual appraised value of the house was $\$ 74,900$, and half of the agents were shown a high anchor of $\$ 83,900$ and half a low anchor of $\$ 65,900$. Those shown the high anchor estimated the appraised value at $\$ 72,196$, and those shown the low anchor estimated $\$ 63,571$. All agents specified that the anchor price did not alter their assessment. This experiment was repeated with a different group of real estate agents and a different house, with similar results.

33 Tverksy and Kahneman, above n 25, at 1128-1130.

34 At 1127.

35 Kahneman, above n 2, at 129.

36 Tverksy and Kahneman, above n 25, at 1127-1128.

37 Kahneman, above n 2, at 7. 
available the risk is judged higher, regardless of the actual probability. ${ }^{38}$ This explains an attitude toward risk that does not accurately reflect probabilities. For example, precautions taken against future natural disasters are highest immediately after a disaster occurs, then decrease as time goes on, even though the probability itself remains constant. ${ }^{39}$

Further, the availability heuristic is affected by vividness and coherence. Vivid associations those that are powerful, clear or distinct - assist in availability and have been demonstrated to affect public perception across a wide range of risks. Research has shown that Americans perceive tornados as deadlier than asthma (although asthma causes 20 times more deaths) and that death by accident was as likely as death by disease (despite disease causing 18 times more deaths), amid other examples. ${ }^{40}$ The vivid nature of deaths by tornadoes and accidents causes people to overestimate their actual incidence in comparison to less vivid, though far more frequent, causes of death. Coherence, where the mind attempts to form a story, also affects availability. Tversky and Kahneman asked subjects to estimate the chances of a massive flood somewhere in North America, then separately asked the chances of a massive flood caused by a Californian earthquake. Subjects estimated the latter to have a greater chance, even though it is a subset of the former. The additional details triggered additional available examples to form a higher estimate. ${ }^{41}$

Another important heuristic is "salience". A rational consumer, assessing the cost of a contract, would give each cost characteristic the appropriate weight in an overall evaluation. ${ }^{42}$ A consumer with bounded rationality, however, is unable to perform the complex calculations that some contracts require, especially those with multiple price dimensions over time (for example, interest rates and the probability of paying fees). ${ }^{43}$ Consumers will instead focus on a limited number of salient features, including those promoted by the seller in advertising, and ignore non-salient features that nonetheless can impact on the cost of the contract. ${ }^{44}$ As Bar-Gill states, "[t]he imperfectly rational consumer deals with complexity by ignoring it." 45

38 Thaler and Sunstein, above n 3, at 24.

39 Paul Slovic, Howard Kunreuther and Gilbert White "Decision Processes, Rationality and Adjustment to Natural Hazards" in Paul Slovic (ed) The Perception of Risk (Taylor and Francis Group, London, 2000) at $13-15$.

40 Kahneman, above n 2, at 137-138.

41 Amos Tversky and Daniel Kahneman "Extensional versus intuitive reasoning: The conjunction fallacy in probability judgment" (1983) 90 Psychol Rev 293 at 307-308.

42 Bar-Gill, above n 9, at 18 .

43 At 18 and 52.

44 At 18 .

45 At 18. 
A final heuristic is the assumption of "normality" and "symmetry". It is naturally easier to estimate potential outcomes by assuming that probability is normally distributed around the mean, although it may not be. ${ }^{46}$ This simplistic approach is even used when probability is taught in universities, including graduate schools, ${ }^{47}$ and can erroneously skew estimates of an expected value where the actual distribution is asymmetrical. ${ }^{48}$ A related point is that an outcome's probability should always be considered with its magnitude. ${ }^{49}$ Taleb provides the example of a gamble with a 999/1000 probability of winning $\$ 1$, and a $1 / 1000$ chance of losing $\$ 10,000$. The median outcome, and that which most people would expect to happen, is the gain of a dollar; but the mean or expected value outcome is to lose slightly more than $\$ 9 .{ }^{50}$

\section{Biases}

Under bounded rationality, another cause of judgement error is cognitive biases which are "systematic deviations from the economic model of rational decision making which can lead us to make judgments and decisions which are not always in our best interest." 51

One significant cognitive bias is the "optimism bias", which Jolls and Sunstein define as "the tendency of people to believe that their own probability of facing a bad outcome is lower than it actually is." 52 This is caused by overweighting positive outcomes which cognitively are more pleasant to consider. Positive outcomes are also easier to imagine due to the limited range of successful outcomes. ${ }^{53}$ In contrast, negative outcomes are less pleasant to consider, and tend to be diffused across a wide range of possible occurrences. ${ }^{54}$ Negative outcomes can also be caused by factors unknown to the decision-maker, which by their nature are inherently difficult to make allowances for. ${ }^{55}$ The

46 Nassim Taleb Fooled by Randomness (2nd ed, Random House Inc, New York, 2004) at 97-99.

47 At 99.

48 At 99.

49 At 98 and 99

50 At 99 .

51 Behavioural Insights Team A review of optimism bias, planning fallacy, sunk cost bias and groupthink in project delivery and organisational decision making (Literature review prepared for the United Kingdom Department of Transport, July 2017) <www.bi.team> at 4.

52 Jolls and Sunstein, above n 4, at 204.

53 Roger Buehler, Dale Griffin and Michael Ross "Inside the Planning Fallacy: The Causes and Consequences of Optimistic Time Predictions" in Thomas Gilovich, Dale Griffin and Daniel Kahneman (eds) Heuristics and Biases: The Psychology of Intuitive Judgement (Cambridge University Press, Cambridge, 2002) 250 at $253-$ 255.

54 At 253-255.

55 Kahneman, above n 2, at 247. 
optimism bias is further caused by a tendency to focus too much on the role of skill and not enough on the role of luck. ${ }^{56}$ Studies have shown, for example, that American MBA students overestimate their likely starting salary despite clear statistical data, ${ }^{57}$ and New Zealand psychology students overestimate their ability to repay student debt. ${ }^{58}$ As Kahneman states: ${ }^{59}$

Most of us view the world as more benign than it really is, our own attributes as more favorable than they truly are, and the goals we adopt as more achievable than they are likely to be. We also tend to exaggerate our ability to forecast the future, which fosters optimistic overconfidence.

Thaler points out that the optimism bias "can explain a lot of individual risk taking, especially in the domain of risks to life and health." ${ }^{60}$ For instance, a smoker may know the overall statistics linking smoking to cancer, but still believe they themselves have a smaller chance of contracting the disease. ${ }^{61}$ The optimism bias is also closely related to overconfidence; around 90 per cent of people think they are above average drivers, a mathematically impossible assessment that has been shown in a wide variety of activities and fields. ${ }^{62}$

A second bias is "loss aversion". Simply put, people fear losses more than they value gains. A simple example is a gamble on a coin toss, which offers a $\$ 150$ gain for heads, and a $\$ 100$ loss for tails. ${ }^{63}$ Many will not take that bet, even though the expected value is positive, as the potential pain of the loss looms larger than the potential benefit of the gain; they are loss averse. ${ }^{64}$ Jolls and Sunstein describe how loss aversion can be used to produce framing effects: as "framing outcomes as losses rather than gains will generally affect how people will respond." 65 They cite the example of

56 At 259

57 David Armour and Shelley Taylor "When Predictions Fail: The Dilemma of Unrealistic Optimism" in Thomas Gilovich, Dale Griffin and Daniel Kahneman (eds) Heuristics and Biases: The Psychology of Intuitive Judgement (Cambridge University Press, Cambridge, 2002) 334 at 334-336.

58 Hamish Seaward and Simon Kemp "Optimism Bias and Student Debt" (2000) 29 NZ J Psychol 17 at 18-19.

59 Kahneman, above n 2, at 225.

60 Thaler and Sunstein, above n 3, at 32.

61 At 32

62 Iain McCormick, Frank Walkey and Diane Green "Comparative Perceptions of Driver Ability - A Confirmation and Expansion" (1986) 18 Accid Anal \& Prev 205 at 205-207; and Thaler and Sunstein, above n 3 , at 32 .

63 Kahneman, above n 2, at 283.

64 At 284

65 Jolls and Sunstein, above $n$ 4, at 205-206. 
advertisements for breast-feeding, which are more impactful if negative instead of positive, so consequences are emphasised such as increased risk of disease for babies not breast-fed. ${ }^{66}$

A final bias is "present-bias" or "temporal discounting". People value a benefit delivered in the present more highly than the same benefit delivered in the future, thereby discounting the future. BarGill likens this to myopia where people "care more about the present and not enough about the future." ${ }^{67}$ Some emphasis on the present is rational as future benefits should be weighted by the probability of occurrence as well as the time value of money. ${ }^{68}$ Traditional economics has attempted to model this through exponential discounting, which assumes a constant discount rate over time. ${ }^{69}$ However, a constant discount rate "ignores the human tendency to grab immediate rewards and to avoid immediate costs", which gives a heavy bias to the present. ${ }^{70}$ Due to the human tendency to focus on the present, benefits delayed today hurt more than the same benefit delayed in the future, while costs put off today are valued more highly than similarly delayed costs in the future.

This is supported by neurological research where functional MRIs have revealed that the brain processes immediately available rewards in the limbic system, which is associated with dopamine, a neurotransmitter for pleasure. In contrast, delayed rewards are processed in a different brain area not related with the release of dopamine. ${ }^{71}$ Present-bias explains why people will plan to stop smoking or eating fat-laden foods beginning tomorrow, instead of today; today is valuable to our current self and we can implement our plan for the long term later. ${ }^{72}$ Homer Simpson aptly summed this up as "[t]hat's a problem for future Homer." 73 This time inconsistency also applies to loans. People have been shown to value low initial teaser rates more than long-term rates although this is irrational; long-term rates may be higher, last longer, and are ultimately far more determinative of the actual costs of borrowing. ${ }^{74}$

Homo economicus would never be swayed by a temporary teaser rate, instead they would always consider the costs of the contract as a whole. However, in the real world, due to bounded rationality

66 At 206

67 Bar-Gill, above n 9, at 21.

68 At 21-22.

69 Thaler and Sunstein, above n 3, at 90

70 Ted O'Donoghue and Matthew Rabin "Doing it now or later" (1999) 89 Am Econ Rev 103 at 103-106.

71 Samuel McClure and others "Separate Neural Systems Value Immediate and Delayed Monetary Rewards" (2004) 306 Science 503 at 503 and 506.

72 Bos, above n 6, at 108 .

73 "MoneyBart" The Simpsons Season 22 Episode 3 (FOX, 10 October 2010).

74 Stefano DellaVigna "Psychology and Economics: Evidence from the Field" (2009) 47 J Econ Lit 315 at 320 321. 
and cognitive biases such as the optimism bias, borrowers will borrow amounts and/or at interest rates not in their best interests. When this occurs to vulnerable consumers, great harm can be inflicted, forcing the government to intervene in the consumer credit market.

\section{NEW ZEALAND'S CONSUMER CREDIT MARKET, LAWS AND REGULATIONS}

In New Zealand, attempts to address problems with the consumer credit market were evident as early as the Moneylenders Act 1908, which required the registration of anyone lending money at over a 10 per cent interest rate. ${ }^{75}$ Subsequent legislation included the Credit Contracts Act 1981 and the Hire Purchase Act $1971,{ }^{76}$ which were repealed when the Credit Contracts and Consumer Finance Act 2003 (CCCFA) came into effect in 2005. ${ }^{77}$ The CCCFA was designed to address concerns about unfairness to consumers of some of the earlier enactments as well as the significant technological changes that had occurred in the previous decades. ${ }^{78}$ It explicitly distinguished between consumer and commercial credit transactions ${ }^{79}$ and introduced limits on unfair credit terms, as well as required new disclosure obligations. ${ }^{80}$ The objective of the disclosure obligations was to promote transparency such that consumers' acquisition of debt occurred in an efficient market fuelled by competitive lenders. ${ }^{81}$ These mandated disclosures focused on product attributes, such as credit limit, annual interest rate, and method of charging interest, and were required either before the contract was made or within five days thereafter. ${ }^{82}$

However, the CCCFA did not anticipate structural changes to the lending market. New Zealand has three tiers of lenders: ${ }^{83}$ the first-tier is made up of the 27 registered banks, the second-tier consists of savings institutions and deposit taking finance companies, while the third encompasses non-deposit taking finance companies. ${ }^{84}$ Historically, unsecured consumer lending was undertaken by the second

75 Moneylenders Act, ss 3(9) and 4.

76 Laws of New Zealand Consumer Credit at [10].

77 Credit Contracts and Consumer Finance Act 2003 [CCFA], s 140.

78 Laws of New Zealand, above n 76, at [10].

79 CCCFA, s 11.

80 CCCFA (as at 3 September 2007), ss 3, 11, 13 and 17-19; and Laws of New Zealand, above n 76, at [10].

81 Elizabeth Meade Responsible Lending: Irresponsible Regulation of Consumer Credit in New Zealand? (LLB (Hons) Dissertation, University of Otago, 2012) at 12.

82 CCCFA, s 17 and Schedule 1.

83 Colmar Brunton Using a third-tier lender: experiences of New Zealand borrowers (paper prepared for Ministry of Consumer Affairs, August 2011) at 1.

84 Ministry of Consumer Affairs Third-tier Lender Desk-based Survey 2011 (July 2011) at 2-3; and Sam Green, Nick Robertson and Dr Ganesh Nana Making sense of the numbers: the harm from high cost lending - the 
and third-tier institutions, with second-tier institutions also issuing residential and business loans. ${ }^{85}$ In 2008, due to the global financial crises, the Reserve Bank of New Zealand lowered the Official Cash Rate (OCR) from over eight per cent to 2.5 per cent. ${ }^{86}$ This expansionary monetary policy encouraged registered banks to increase their residential and business lending, crowding out the second-tier lenders, which all but disappeared. ${ }^{87}$ The sharp contraction of the second-tier enabled third-tier lenders to expand into consumer lending areas previously served by the second-tier, "particularly in the high cost short term lending market." 88 This drove, and was driven by, the ability of third-tier lenders to issue loans faster and more easily than their deposit taking counterparts ${ }^{89}$ who operated under more onerous regulations. ${ }^{90}$ Growth in the third-tier was further fuelled by the low OCR, which allowed non-deposit taking institutions to borrow from registered banks at low interest rates, then use that money to grow their balance sheet and increase their ability to offer consumer loans.

By 2011, the New Zealand government was increasingly concerned about the harm caused by third-tier lenders. ${ }^{91}$ Surveys and interviews revealed that despite the 2005 changes from the CCCFA, lenders were still taking advantage of those with limited financial literacy. ${ }^{92}$ Such borrowers lacked "understanding [of] their rights as a borrower, the terms and conditions of loan contracts, and the impact of high interest rates on the total payable amount."93 Third-tier lenders would also target low income earners who could not access lower rate loans from first-tier lenders. ${ }^{94}$ At risk groups such as Māori, Pasifika and recent immigrants were disproportionately affected. ${ }^{95}$ Auckland City Mission

case for increased and improved regulation (Business and Economic Research Limited, Wellington, 2019) at 9.

85 Green, Robertson and Nana, above n 84, at 9.

86 At 6.

87 At 9 .

88 Green, Robertson and Nana, above n 84, at 10.

89 Ministry of Consumer Affairs, above n 84, at 3; and Colmar Brunton, above n 83, at 3.

90 See generally the Building Societies Act 1965, the Friendly Societies and Credit Unions Act 1982, and the Non-bank Deposit Takers Act 2013.

91 Colmar Brunton, above n 83, at 2 .

92 At 19.

93 At 24.

94 (27 May 2014) 699 NZPD at 18357.

95 Colmar Brunton, above n 83, at 7-8. 
listed high-cost debt as a key driver keeping people trapped in poverty. ${ }^{96}$ Those who struggle to pay back high-cost loans enter a "cycle of debt and despair," 97 with consequences for their physical and mental health, including the "crippling" burden "that must be borne when people are forced to live in a state of unmanageable and inescapable debt." 98

The National Government responded to these problems with the Credit Contracts and Consumer Finance Amendment Act 2014 (2014 Amendments). This was a principle-based approach which required lenders to exercise the "care diligence and skill of a responsible lender" when advertising to or subsequently dealing with borrowers. ${ }^{99}$ It further required a lender to make "reasonable inquiries" that the loan suited the borrowers' needs and loan-servicing ability, ${ }^{100}$ and to make the borrower "reasonably aware of the full implications of entering into the agreement." ${ }^{101}$ The 2014 Amendments also mandated that product characteristics such as annual interest rates be disclosed before the contract was made, ${ }^{102}$ that fees were based on costs (not profit-drivers), ${ }^{103}$ and introduced a non-binding Responsible Lending Code (RLC). ${ }^{104}$

The overall approach aimed to protect vulnerable consumers and to facilitate "the fair, efficient and transparent operation of consumer credit markets." 105 In parliamentary discussions, National MPs stressed the importance of credit markets to the "sound operation of a modern economy," which necessitated getting the balance between efficient markets and vulnerable consumers "right." ${ }^{106}$ In contrast, while Labour MPs supported the legislation, they did not think the principle-based approach went far enough because Labour's proposed interest rate cap was not included in the legislation. Labour MPs questioned relying on the market to set interest rates, as they believed borrowers would

96 Emily Gorden Speaking for Ourselves: The truth about what keeps people in poverty from the people that live it (Auckland City Mission, 2014) at 2.

97 (27 May 2014) 699 NZPD at 18355.

98 Gorden, above n 96, at 6.

99 Credit Contracts and Consumer Finance Amendment Act 2014 [2014 Amendments], ss 9C(1) and 9C(2).

100 Section $9 \mathrm{C}(3)(\mathrm{a})$.

101 Section $9 \mathrm{C}(3)(\mathrm{b})$.

102 Section 15.

1032014 Amendments, s 30, which replaced s 43 of the CCCFA.

104 Sections 9E, 9F, 9G.

105 (27 May 2014) 699 NZPD at 18353.

106 At 18357. 
enter into high-interest loans of 50 per cent or even 1000 per cent and then be unable to make repayment. ${ }^{107}$

The new disclosure regime was implemented successfully as detailed by the Ministry of Business, Innovation and Employment (MBIE) in its 2018 review of the 2014 Amendments. Stakeholders, including lenders, borrowers and community groups, reported that overall the "responsible lending changes have led to improvements in the information available to consumers, and in lender processes and decision-making." ${ }^{108}$ Both the Commerce Commission and MBIE confirmed increased product disclosure in separate studies, ${ }^{109}$ which showed, for example, that the percentage of finance companies disclosing interest rates and fees in web-based advertisements increased from under 40 per cent to over 80 per cent. ${ }^{110}$

However, despite increased disclosure of interest rates and fees, the harm associated with highcost lending persisted as it continued to be linked with, and was a driver of, poverty. Evidence from numerous sources paints a daunting picture. ${ }^{111}$ The Commerce Commission found that 25 per cent of loans, made by the 10 high-cost lenders surveyed, resulted in at least one missed or re-arranged payment, and for one lender, 63 per cent of loans were not paid in full accordance to the terms and conditions. ${ }^{112}$ This incidence of non-repayment is far higher than for loans from first-tier lenders. Moreover, missed payments on high-cost loans are more problematic than for other loans due to high interest rates causing a debt spiral. An MBIE survey of Māori Housing New Zealand tenants revealed 43 per cent had debt pursued by debt collectors, against a backdrop of 89 per cent of tenants reporting they had run out of food at some point due to lack of money. ${ }^{113}$ A social service provider working with low-income families advised MBIE that 95 per cent of its client families, which included 900 children, were "carrying unaffordable debt". ${ }^{114}$

107 At $18355-18357$ and $18358-18361$.

108 Ministry of Business, Innovation and Employment Review of consumer credit regulation (Discussion Paper, June 2018) at 9.

109 Commerce Commission Lender Website Review 2017/2018 (June 2018); and Ministry of Business, Innovation and Employment 2018 Desk-based study of Lenders: An overview of the New Zealand lender landscape and lender advertising and disclosure practices (2018).

110 Ministry of Business, Innovation and Employment, above n 109, at 15-16.

111 Ministry of Business, Innovation and Employment Impact Statement: CCCFA Amendments (September 2018) at 8,11 .

112 Commerce Commission Commerce Commission submission on Discussion Document: Consumer Credit Regulation (August 2018) at [14].

113 Ministry of Business, Innovation and Employment, above n 111, at 12.

114 At 12 . 
The scale of the problem is further illustrated by the 2016/17 Summary Instalment Orders which recorded that 32 per cent of debtors who entered insolvency reported "excessive use of credit facilities" as the primary cause. ${ }^{115}$ This was greater than insolvency caused by "unemployment or loss of income." 116 These results echo findings compiled by Fincap. ${ }^{117}$ Of borrowers with a high-cost loan who sought Fincap's assistance, 27 per cent pointed to the high-cost loan as "the primary reason for their financial distress" while 19 per cent indicated it as the sole reason. ${ }^{118}$

The Labour Government moved to address these concerns with the 2019 Amendments, the centrepiece of which was a cap on the maximum costs of borrowing, limiting the total interest and fees payable on a high-cost loan to the amount of the initial loan. ${ }^{119}$ High-cost loans were defined as having an annual interest rate (including default rates) greater than 50 per cent. ${ }^{120}$ For example, if a person borrowed $\$ 500$ at an annual rate of 50 per cent or greater, the most the borrower would ever have to repay is $\$ 1000$ : $\$ 500$ for the principal and a maximum of $\$ 500$ in total in interest and fees. Furthermore, daily interest rates were limited to 0.8 per cent per day, ${ }^{121}$ compound interest was prohibited, ${ }^{122}$ and default fees on high-cost loans were capped at $\$ 30 .{ }^{123}$ Under the 2019 Amendments, lenders were prohibited from making high-cost loans to borrowers who already had high-cost loans with other lenders, ${ }^{124}$ or repeat loans to their own customers who had entered into two high-cost loans in the last 90 days. ${ }^{125}$

The 2019 Amendments also affected the general loan industry. Lenders were required to record and demonstrate that the method and data they use for determining their fees were not unreasonable. ${ }^{126} \mathrm{RLC}$ advertising standards were introduced, augmenting previous restrictions that

115 At 11. Summary Instalment Orders are now referred to as Debt Repayment Orders.

116 At 11 .

117 Fincap is the financial budgeting and assistance service sponsored by the Ministry of Social Development.

118 Green, Robertson and Nana, above n 84, at 12 and 17.

1192019 Amendments, s 25: which inserted s 45E into the CCCFA.

120 Section 25: which inserted s 45C into the CCCFA. The 2019 amendments refer to "high-cost consumer credit contract", which for simplicity and consistency I will refer to as "high-cost loans".

121 Section 25: which inserted s $45 \mathrm{H}$ into the CCCFA.

122 Section 25: which inserted s 45I into the CCCFA.

123 Section 25: which inserted s 45J(7) into the CCCFA. If no regulations are made otherwise, the prescribed amount is $\$ 30$.

124 Section 25: which inserted s 45F into the CCCFA.

125 Section 25: which inserted s 45G into the CCCFA.

126 Section 24: which inserted s 41A into the CCCFA. 
had only prohibited misleading and deceptive advertising. ${ }^{127}$ The RLC could also prescribe what "reasonable inquiries" into the affordability and suitability of a loan would entail. ${ }^{128}$ Finally, there was a general emphasis on requiring lenders to take greater care in making loans, including retaining documents related to loan affordability analysis ${ }^{129}$ and requiring directors of consumer-lending companies to be certified as a "fit and proper" person. ${ }^{130}$

In Parliamentary debates, the Minister of Commerce and Consumer Affairs was clear that the 2014 Amendments did not sufficiently protect vulnerable consumers and that the caps on costs, interest rates and fees in the 2019 Amendments were necessary to address the harm from high-cost loans. The Minister cited the "overwhelming number of submissions" in support of caps from people who "work on the front line with vulnerable borrowers and see the everyday harms and irresponsible high-cost lending damage that can be caused." ${ }^{131}$ An MBIE analysis of the 435 submissions received on the Bill supported this claim. ${ }^{132}$ National MPs, while generally supportive of the Bill, raised concerns about the impact of the caps, particularly the 0.8 per cent daily rate cap on credit availability. ${ }^{133} \mathrm{~A}$ decline in availability would reduce much-needed borrowing options and could compel people to turn to family members or the unregulated black market. ${ }^{134}$ Borrowing from family members raises special concerns, as family members could also be in precarious financial positions, thus spreading the problem. ${ }^{135}$ Both parties agreed on the importance of loans being made appropriately and that many problems with high-cost lending would be solved if the lender were to exercise true care in determining the affordability and suitability of each loan for the individual borrower. ${ }^{136}$

127 Section 12: which inserted new language into s 9F(1)(b)(i) of the CCCFA.

128 Section 6: which inserted s 5A into the CCCFA; and Section 53: which inserted s 138(1)(abd) into the CCCFA. The changes in the responsible lending code are due later this year, see below.

129 Section 11: which inserted CCCFA, s 9CA.

130 Section 30: which inserted CCCFA, s 131A.

131 (12 December 2019) 743 NZPD at 15940

132 Ministry of Business, Innovation and Employment "Credit Contract Legislation Amendment Bill: Officials' Report to the Finance and Expenditure Committee" (August 2019) at [20].

133 (21 November 2019) 743 NZPD at 15371; (10 December 2019) 743 NZPD at 15753; and (12 December 2019) 743 NZPD at 15941.

134 (21 November 2019) 743 NZPD at 15371-15372; and (12 December 2019) 743 NZPD at 15941.

135 (19 November 2019) 743 NZPD at 15241-15242; (12 December 2019) 743 NZPD at 15941; and Ministry of Business, Innovation and Employment "Credit Contracts Legislation Amendment Bill: Briefing 3 to the Finance and Expenditure Committee" (August 2019) at [19].

136 (30 April 2019) 737 NZPD at 10574-10575; (19 November 2019) 743 NZPD at 15240-15242; (21 November 2019) 743 NZPD at 15371; and (12 December 2019) 743 NZPD at 15939-15941. See also Ministry of 
In summary, over the last 15 years Parliament has attempted, with varying success, to reduce harm from high-cost lending by first mandating increased disclosure about product characteristics and subsequently by restricting the products available through capping costs, interest rates and fees. To better analyse the impact and efficacy of government actions, it is necessary to first understand the basis of high-cost loans. Why do people borrow money at high interest rates and costs, often to their detriment and contrary to what is expected under a rational choice model?

\section{EXPLANATIONS OF THE NATURE OF HIGH-COST LOANS}

While the rational choice model can account for some high-cost loans, most of them are better explained by bounded rationality.

However, Bar-Gill suggests, and Epstein concurs, that an analysis of consumer decision-making in an industry should begin with the rational choice model. ${ }^{137}$ According to Bar-Gill, such analysis should: 138

... first consider possible rational-choice, neoclassical economics explanations for the observed contracts and prices. The behavioral-economics theory enters only after the standard accounts are shown to be unsatisfactory or incomplete. Indeed, the failure of the standard approach provides the impetus for developing an alternative, behavioral-economics theory.

There is indeed a robust case for some high-cost loans under the rational choice model. Certain demographics, including those with low socioeconomic status and bad credit ratings, have difficulty accessing low-interest loans from first-tier providers. Even proponents of strict high-cost lending controls acknowledge the rational demand for high-cost loans as a remedy to meet short-term liquidity constraints; ${ }^{139}$ it can be rational to take out a high-cost loan to keep a vehicle running to get to work, or to pay a power bill and save a reconnection fee. ${ }^{140}$

Further, on the supply side, the costs of delivering such loans are disproportionately higher as these loans tend to be smaller and for a shorter time period, resulting in higher transaction costs and the greater allocation of fixed costs to these smaller amounts. ${ }^{141}$ Providing credit to those with bad

Business, Innovation and Employment "Credit Contracts Legislation Amendment Bill: Initial Briefing to the Finance and Expenditure Committee" (June 2019) at [38]-[39].

137 Bar-Gill, above n 9, at 7, 52 and 119; and Richard Epstein "Behavioural Error, Misguided Regulation, and Technical Innovation: Some Observations about Oren Bar-Gill's Seduction by Contract" (2014) 9(1) Jerus Rev Leg 87 at $87-88$.

138 Bar-Gill, above n 9, at 7.

139 Ministry of Business, Innovation and Employment, above n 108, at 4.

140 Green, Robertson and Nana, above n 84, at 31.

141 Save My Bacon Ltd "Submission to the Parliamentary Finance and Expenditures Committee on the Credit Contracts Amendment Bill " at [6] 
credit ratings is also costly due to the increased probability of default. Finally, some high-cost loans are complex and priced accordingly, due to consumer heterogeneity as "different borrowers have different preferences and face different constraints." 142

While the rational choice model underpins some high-cost lending, it cannot explain the size of that market nor the scale of associated problems. A rational consumer would accurately estimate all charges and contingent probabilities, such that only a handful who experienced "bad luck" would get into trouble. However, the Commerce Commission survey revealed that 25 per cent of borrowers miss payments, and one high-cost lender admitted that over half of his customers failed to service the loan on the agreed terms. ${ }^{143}$ Even if a market can be shown to behave rationally for some consumers, rational choice theory would still be unsatisfactory if most users are "shown to fall short of the perfect rationality ideal." 144

For many consumers, high-cost loans are a market failure best explained by behavioural economics. Bar-Gill argues the optimism bias is a key driver behind the irrational demand for harmful lending products. This bias leads borrowers to overestimate their ability to repay the loan given their current income, as well as something as mundane as their ability to remember to pay it. ${ }^{145}$ People also tend to underestimate the probability of an income or expense shock, such as the chance of being in an accident, developing a health problem, or "getting fired from a job."146 Submissions to the Parliamentary Finance and Expenditures Committee for the 2019 Amendments (FEC) showed such events causing problematic loans. ${ }^{147}$ Furthermore, some of the most vulnerable are people without jobs at the time they borrow. Those who have recently lost a job are prone to substantial borrowing

142 Bar-Gill, above n 9, at 76. Bar-Gill writes about credit cards, but the fundamental economic principle still applies.

143 Commerce Commission, above n 112, at [14].

144 Bar-Gill, above n 9, at 79. Bar-Gill writes about credit cards, but the principles apply to high-cost loans as well.

145 At 90 .

146 Jolls and Sunstein, above n 4, at 204.

147 See generally Christchurch Budget Services Inc "Oral Submission to the Parliamentary Finance and Expenditures Committee on the Credit Contracts Amendment Bill" at 2; Christians Against Poverty New Zealand "Submission to the Finance and Expenditure Select Committee on the Credit Contracts Legislation Amendment Bill" at 8; Citizens Advice Bureau "Submission to the Finance and Expenditure Select Committee Credit Contracts Legislation Amendment Bill" at 2; and Sarah Newham "Submission to the Finance and Expenditure Committee on the Credit Contracts Legislation Amendment Bill" at 2. 
and will tend to underestimate the length of time to find a job, ${ }^{148}$ or overestimate their eventual starting salary. ${ }^{149}$

Another driver of irrational demand for harmful lending products is present-bias. Myopic consumers will focus on short-term benefits and pay insufficient attention to long-term costs. ${ }^{150}$ American research shows that individuals who are present-biased have "significantly higher amounts of credit card debt, controlling for disposable income, other socio-demographics, and credit constraints." ${ }^{151}$ This indicates a preference for current consumption at the expense of deferred costs. The Christchurch Budget Service (CBS) claims the "vast majority" of their clients' debt "relates to a desire for instant gratification driving impulsive consumer spending." 152 CBS blames this on payday lenders offering "drive-thru lending" and retailers "pursuing impulsive shoppers." 153 Such sentiment is further echoed throughout the FEC submissions. ${ }^{154}$

Finally, the inability of some borrowers to comprehend fully the total possible cost of their loan drives further demand. For instance, only 32 per cent of New Zealanders understand the concept of compound interest. ${ }^{155}$ According to Berl: ${ }^{156}$

... data indicates that while people believe that they will be able to repay the principle of the loan, they do not consider the impact that interest payments and fees will have on the total amount to be repaid.

Borrowers, faced with complicated math around interest rates and the probability of contingent or default fees, use mental shortcuts to simplify matters; they expect the total amount to be repaid to be closely related to the principal borrowed. They ignore or minimise the risk of missed payments leading

148 Bar-Gill, above n 9, at 88

149 Or, at the very least, for students predicting the starting salary of their job after school. See Armour and Taylor, above $n$ 57, at 334-336.

150 Bar-Gill, above n 9, at 53.

151 Stephen Meier and Charles Sprenger "Present-biased preferences and credit card borrowing" (2010) 2(1) Am Econ J 193 at 193.

152 Christchurch Budget Services Inc, above n 147, at 4.

153 Christchurch Budget Services Inc "Oral Presentation to the Finance and Expenditure Select Committee on the Credit Contracts Legislation Amendment Bill (NZ's Working Class)" at 4.2.

154 CARE Waitakere Trust "Submission to the Finance and Expenditure Select Committee on the Credit Contracts Legislation Amendment Bill" at 5; Christchurch Budget Services Inc, above n 153, at 4.2; and Presbyterian Support Otago "Submission to the Finance and Expenditure Select Committee on the Credit Contracts Legislation Amendment Bill" at 5. See also Gorden, above n 96, at 7.

155 Commission for Financial Literacy and Retirement Income Financial Knowledge and Behaviour Survey (2013) at 6. This compares to, for example, 81 per cent of New Zealanders who understand the entitlement to shared property when a couple separates.

156 Green, Robertson and Nana, above n 84, at 21. 
to spiralling default interest, compound interest and default fees, which can build the debt to levels of magnitudes greater than the original borrowing. Downplaying such worst-case scenarios will cause borrowers to underestimate the true expected cost of the loan; this mispricing (ie thinking that the loan is cheaper to repay than it actually is) will lead to a larger and economically inefficient demand for loans. This comprehension gap may be exacerbated by unnecessarily complex loan contracts; one study found that 70 per cent of loan contracts surveyed buried key information across multiple documents. ${ }^{157}$ These industry observations are inconsistent with the rational choice model.

As Bar-Gill states, "the interaction between consumer psychology and market forces creates a behavioural market failure", which reduces welfare and hurts consumers. ${ }^{158}$ Bar-Gill suggests that "the persistence of a market failure opens the door for considering the potential role of legal intervention." 159 There are two interventions applicable to the New Zealand high-cost loan market. The first is "insulation" to protect consumers from their bad choices. The government largely followed this strategy in the 2019 Amendments, as described in the following section. The second intervention is "debiasing" to counter or lessen the heuristics and biases responsible for the irrational demand for high-cost loans.

\section{INTERVENTION BY INSULATION}

Insulation is a legal intervention which protects people from the bad outcomes generated by their heuristics and biases. ${ }^{160}$ It does so by legislating against the bad outcome itself or by eliminating products and contractual terms. It restricts consumer choice and the operation of a free market. ${ }^{161} \mathrm{In}$ the context of consumer lending, it protects borrowers from the harm caused by high-cost loans by restricting the types of loans as well as the consequences of those loans.

The 2019 Amendments take this approach. The prime example of insulation is the total cost cap on fees and interest. Regardless of terms agreed on between lender and borrower, the borrower will only be responsible for fees and interest of no more than 100 per cent of the amount borrowed. ${ }^{162}$ This is supplemented by caps on default fees and daily interest rates, and the prohibition on compound interest, which further serve to dampen the amount accumulating under that total cost cap. ${ }^{163}$ The prohibitions against repeat borrowing in a 90-day period, as well as against lending to a borrower with

157 Write Limited "Draft Report Submission to the Finance and Expenditure Select Committee on the Credit Contracts Legislation Amendment Bill" at 22-23.

158 Bar-Gill, above n 9, at 34.

159 At 34 .

160 Christine Jolls Behavioural Economics and the Law (Now Publishers Inc, Boston, 2011) at 23.

161 Jolls and Sunstein, above $\mathrm{n}$ 4, at 226.

162 CCCFA, s 45E.

163 Sections 45H, 45I, and 45J. 
a high-cost loan elsewhere, serve to protect consumers from debt spirals when new debt is used to pay off old debt. ${ }^{164}$

However, such an approach is not without costs as it limits products and distorts the market. Simple caps and other restrictions suppress a lender's ability to correlate default risk and costs with the riskiest borrowers, which can lead to cross-subsidisation from low-risk borrowers. ${ }^{165}$ Restrictions will also necessarily curtail the availability of credit; this is especially true for short-term lending which has a higher cost structure. ${ }^{166}$ Reduced credit availability affects all borrowers, including those with a rational demand, for example, to repair a car to travel to a job. Borrowers locked out from commercial credit will either have no money to service their demands or be forced to borrow from family or the illegal market. Familial borrowing may cause problems if family members are also struggling financially, ${ }^{167}$ and family lenders are disproportionately women who are more vulnerable economically and socially. ${ }^{168}$ On the other hand, illegal lending is unregulated, and regulations which drive demand to unregulated markets are clearly counter-productive.

As the 2019 Amendments are currently being phased in, it is difficult predict the impact on New Zealand, however, analysing the United Kingdom experience may be instructive. ${ }^{169}$ Many of New Zealand's amendments, including the total cost cap, are similar to changes to United Kingdom regulation by the United Kingdom's Financial Conduct Authority (FCA) in 2014, though the latter narrowly focused on payday lenders. ${ }^{170}$ As part of its regulatory role, the FCA examined the effect of these changes on consumers and found that between 2013 to 2016, the number of people taking payday loans dropped 55 per cent, while the value fell 60 per cent. ${ }^{171}$ For borrowers who previously used payday loans then stopped, 89 per cent stopped because they did not want or need the product, while only four per cent had been declined. ${ }^{172}$ This suggests that changes in United Kingdom

164 Section $45 \mathrm{G}$.

165 Bar-Gill, above $\mathrm{n} 9$, at 18. This is in relation to credit cards, but the economic principles are the same.

166 Save My Bacon Ltd, above n 141, at [6].

167 See generally CTU Komiti Pasefika "Submission to the Finance and Expenditure Select Committee on the Credit Contracts Legislation Amendment Bill" at 4; and Dr Liz Gordon and others Survey of financial mentoring and budgeting services in Aotearoa on high cost loans, debt collection and other consumer credit issues (Fincap and Community Law Canterbury, Research Report, February 2019) at 16.

168 Gorden, above n 96, at 6.

169 Ministry of Business, Innovation and Employment, above n 111, at 8 and 11.

170 Financial Services and Markets Act 2000 (Regulated Activities) (Amendment) (No 2) Order 2013 (UK), SI 2013/1881 - Part 5 [Amendments of the Consumer Credit Act 1974].

171 Financial Conduct Authority High-cost credit: Including review of the high-cost short-term credit price cap (Feedback Statement FS17/2, July 2017) at [2.56].

172 At $[2.61]$ 
regulations only had a minor impact on consumers. However, the Consumer Finance Association, a trade group, questioned that conclusion, pointing instead to a fall in the acceptance rate of final stage loan applications from 50 per cent to 30 per cent ${ }^{173}$ as evidence of a massive contraction in credit available to consumers. ${ }^{174}$ The FCA figures also did not account for potential new customers of the industry. ${ }^{175}$ In terms of alternatives to credit from payday lenders, the FCA found little evidence of a turn to illegal markets but did show that 25 per cent of declined customers borrowed from family and friends. ${ }^{176}$ The Carnegie UK trust echoed this finding. ${ }^{177}$

The FCA also examined the effect on the payday lending industry, which shrank dramatically, from an estimated 200 payday lenders in 2013 to just 30 active lenders in 2016. Further, the FCA noted several lenders were in the process of winding down. ${ }^{178}$ The FCA also reported a 51 per cent decline in revenues amongst payday firms, and that few if any were profitable. ${ }^{179}$ Following that report, the United Kingdom's largest payday lender, Wonga, collapsed, ${ }^{180}$ and the second largest, Quickquid, closed (though both continued to operate in other countries). ${ }^{181}$ The United Kingdom government encouraged traditional banks to "provide short term affordable credit" to fill the market gap but banks were "reluctant to enter the high-cost lending market." 182

Overall, insulation appears to have mixed results in the United Kingdom: the greatest impact appears to be a decimated lending industry whereas the effects on the consumer are less clear, other than increased borrowing from family. While the United Kingdom data is illuminating, it should be treated with some caution in the New Zealand context. Although the United Kingdom and New

173 Consumer Finance Association Impact of regulation on High Cost Short Term Credit: How the functioning of the HCSTC market has evolved (March 2017) at 16-17.

174 At 16.

175 Financial Conduct Authority, above n 171, at [2.61].

176 At [2.13].

177 Dr Lindsey Appleyard, Carl Packman and Jordon Lazell Payday Denied: Exploring the lived experience of declined payday loan applicants (Carnegie UK Trust, Barrow Cadbury Trust, CBis, and Toynbee Hall, 2018) at 4 and $24-26$.

178 Financial Conduct Authority, above n 171, at [2.50]; and Daniel Tannenbaum "The payday loans industry is worth $£ 228$ million in the UK" (18 July 2018) MoneyBlog <www.paydaybadcredit.co.uk>.

179 Financial Conduct Authority, above n 171, at [2.52] and [2.54].

180 Nicholas Megaw and Caroline Binham "Wonga Collapse after surge of customer complaints" Financial Times (London, 31 August 2018).

181 "QuickQuid: UK's largest payday lending firm to close" BBC News (London, 25 October 2019).

182 Victoria Stace and Professor Jeremy Finn Working Towards a Fairer Consumer Credit Market: A study of the issues in New Zealand's consumer credit market and proposals for reform (Fincap and Borrin Foundation, 2019) at 15; See also Pippa Lane and Laura Rodrigues Filling the gap: Can banks step into the gap left by payday loans - and if so, how? (Citizens Advice, 21 July 2015) at 4-6. 
Zealand have similar cap levels, the United Kingdom regulations were more narrowly focused on loans over 100 per cent interest and under one-year duration. ${ }^{183}$ The New Zealand amendments, which engage at a lower interest rate and without time restrictions, will likely affect more products. Therefore, while the 2019 Amendments may reduce harm, it may also have a greater market-distorting impact on the lending industry and consumers as compared with the United Kingdom.

\section{INTERVENTION BY DEBIASING}

Another option to address the harm from high-cost lending is "debiasing". Jolls and Sunstein define debiasing as a process which attempts to address bounded rationality by reducing or eliminating the biases and heuristics which cause people to behave irrationally. ${ }^{184}$ They use the example of encouraging women to detect breast cancer. If women are too optimistic and underestimate the probability of getting breast cancer, they are less likely to undertake self-examinations. ${ }^{185}$ If that optimism bias could be countered, or "debiased", women would have an accurate understanding of the risk and undertake a commensurate rate of examination.

Jolls and Sunstein suggest that one method of debiasing is information provision. They recommend using information to prompt the availability heuristic to counter the optimism bias. ${ }^{186}$ Continuing with the breast cancer example, they reference the use of detailed stories about people with breast cancer to counter the optimism bias of women around that disease. ${ }^{187}$ They also explain that framing the information in terms of "negative consequences of failing to undertake selfexamination" is more effective than positive approaches (for example, the benefits of catching cancer early). ${ }^{188}$

In the context of high-cost lending, biases such as the optimism bias can cause people to underestimate the cost of high-cost loans, which in turn irrationally increases demand for those loans. If borrowers were debiased and realistic about their chances of repaying a high-cost loan, they would accurately price the cost of the loan and only purchase it when it is in their best interest. A debiasing strategy might, for example, warn potential borrowers of the probability of failing to repay the loan, and the associated financial dangers. ${ }^{189}$

183 The definition "high-cost short-term credit" was made as a rule in the FCA Glossary in the Consumer Credit (Consequential and Supplementary Amendments) Instrument 2014 (Annex A page 9).

184 Jolls and Sunstein, above n 4, at 200.

185 At $210-211$

186 At $209-210$

187 At 209

188 At 210-211.

189 Bar-Gill, above n 9, at 106. 
A debiasing approach has numerous advantages. First, it reduces market distortion as efficient markets depend upon consumers accurately pricing products. ${ }^{190}$ Debiasing can also avoid a blunt decimation of an entire industry, as witnessed in the United Kingdom payday lending industry, or indiscriminately affect the whole range of products available. ${ }^{191}$ Consumers unencumbered by the optimism bias would have a full range of products to rationally choose from, and lenders would not need to cross-subsidise losses from high-risk borrowers with revenue from other customers. ${ }^{192}$

There are, however, disadvantages arising from the practical difficulties of implementing a debiasing strategy. Jolls and Sunstein point to the problem of heterogenous actors, that "not all individuals are likely to be boundedly rational, at least not to the same degree". ${ }^{193}$ Debiasing strategies could lead to "overshooting", rendering some consumers irrationally pessimistic where they had previously been irrationally optimistic, or even introduce pessimism among those with no previous optimism bias. ${ }^{194}$ Alternatively, the debiasing strategy might not work well enough, with slightly less optimistic consumers still making inefficient choices and undermining the government's policy objectives.

\section{EXPERIMENTAL DESIGN ${ }^{195}$}

While there is a general acceptance in law and behavioural economics that debiasing facilitates rational decision-making, the efficacy of strategies to reduce bias needs to be tested to understand the potential impact. ${ }^{196}$ As part of the research for this article, a survey experiment was designed to measure the impact of debiasing strategies on consumers who may take out high-cost loans. Participants were shown an advertisement for high-cost loans and asked whether they would borrow money given different scenarios and experimental conditions. There were three components to the survey of potential consumers of high-cost loans: the reason for considering a loan, the method of communication, and the nature of the communication itself.

190 At 25.

191 Save My Bacon Ltd, above n 141, at [3]; and Cash Converters "Submission to the Finance and Expenditure Select Committee on the Credit Contracts Legislation Amendment Bill" at 7-10.

192 Cash Converters estimated that fewer than 1 per cent of its customers have problems with high-cost loans, as evidenced by those who interact with Fincap: Cash Converters, above n 191, at 6.

193 Jolls and Sunstein, above n 4, at 228.

194 At $228-231$.

195 Special thanks to Dr Anne Macaskill, Lecturer in Behavioural Analysis at the VUW School of Psychology, for assisting with this design.

196 Bar-Gill, above n 9, at 40, 42 and 105; and Jolls and Sunstein, above n 4, at 226 and 230. 


\section{A Reason for Loan}

The survey asked participants to consider one of two randomly assigned reasons for the loan: a necessity or a family obligation. The details of each scenario were suggested by submissions to the FEC as well as other sources describing the source of problem debt in New Zealand. ${ }^{197}$

The necessity scenario consisted of an $\$ 850$ electric bill that was months overdue, and included a threat of disconnection by the power company. ${ }^{198}$ Electricity was chosen as it was frequently listed as a necessity in submissions to the FEC, ${ }^{199}$ and consumer surveys have shown that six per cent of households have taken out a loan to pay the power bill. ${ }^{200}$ The figure of $\$ 850$ was based on the approximate cost of four months of electricity in winter for the average household. ${ }^{201}$

The family obligation scenario was structured similarly, though participants were requested to imagine needing money to attend a family wedding. Submissions to the FEC indicated that a large part of problem debt originated from cultural and family obligations, especially among Pacific people ${ }^{202}$ such cultural expectations were also listed as the top factor in Pacific people indebtedness in a Families Commission study. ${ }^{203} \$ 850$ was used for consistency with the necessity scenario, and seemed reasonable for a trip for a family.

A third scenario, about borrowing money for a holiday, was discarded. While there is some evidence of problem borrowing for luxury items, ${ }^{204}$ a pilot survey of five participants revealed that not a single subject would borrow under that scenario. This inconsistency with observed behaviour pertaining to the use of high-cost loans for luxury items may merit further future investigation.

197 The exact wording of the scenarios is in Appendix A.

198 NZD850 was converted to GBP450 in the survey of United Kingdom residents: See below.

199 See generally CARE Waitakere Trust, above n 154, at 5; Good Shepherd NZ "Submission to the Finance and Expenditure Committee on the Credit Contracts Legislation Amendment Bill" at 4; Presbyterian Support Otago, above n 154, at 7; Porirua Salvation Army "Submission to the Finance and Expenditure Committee on the Credit Contracts Legislation Amendment Bill" at 2; and Sarah Newham, above n 147, at 2.

200 Consumer New Zealand "Power company satisfaction survey 2020" (3 June 2021) <consumer.org.nz>.

201 Ministry of Business, Innovation and Employment "Electricity Cost and Price Monitoring" (10 June 2021) $<$ mbie.govt.nz $>$.

202 See generally CTU Komiti Pasefika, above n 167, at 2; Christians Against Poverty New Zealand "Submission to the Finance and Expenditure Committee on the Credit Contracts Legislation Amendment Bill" at 2; Gordon and others, above n 167, at 16; CARE Waitakere Trust, above n 154, at 5; and Community Law "Submission to the Finance and Expenditure Committee on the Credit Contracts Legislation Amendment Bill" at 4.

203 Families Commission Pacific Families and Problem Debt (Research Report 6, November 2012) at 10.

204 Christchurch Budget Services Inc, above n 153, at 4.2; and CARE Waitakere Trust, above n 154, at 5. 


\section{B Method of Communication}

The survey used a mock text advertisement due to the prevalence of text advertising in the industry. ${ }^{205}$ Advertising is also a common way the Commerce Commission and MBIE monitor the industry for compliance with regulations. ${ }^{206}$ As such it is an effective way to research new approaches. Advertising as a conduit for debiasing strategies is also useful as the CCCFA allows for the setting of advertising standards in the RLC. ${ }^{207}$

For the experiment, participants were asked to consider an advertisement from a lender, offering to help people who needed money at a "5\% interest per month, $60 \%$ annual interest rate." Different experimental conditions were then added to that basic advertisement, as detailed below.

\section{Nature of Communication}

The third component of the design was experimental conditions. Each participant was shown a series of advertisements, each of which contained one of six different conditions: The Control condition, the "Current Law" or insulation condition, and four debiasing conditions. ${ }^{208}$

\section{Control condition}

The first condition was the Control. This was designed to be a basic generic advertisement for high-cost loans, offering a loan with five per cent monthly and 60 per cent annual interest. ${ }^{209}$ It aimed to measure how participants would react when neither insulation nor debiasing strategies were present.

\section{Insulation condition - "Current Law"210}

In the second condition, participants were shown an advertisement informing them of the current law. This consisted of the basic advertisement in the control above followed by a description of the

205 Over 70 per cent of lenders have websites, over 40 per cent NZ Facebook pages, and 19 per cent use newspaper advertisements: Ministry of Business, Innovation and Employment Lender Desk-based Survey 2015: Examining the advertising practices of New Zealand lenders (2015) at 27.

206 See generally Ministry of Business, Innovation and Employment, above n 109; Commerce Commission, above n 109; Ministry of Business, Innovation and Employment, above n 205; and Ministry of Consumer Affairs, above $\mathrm{n} 84$.

207 CCCFA, ss 9C(3)(b)(i)(A) and 9F(1)(b)(i).

208 The exact wording of the conditions is included in Appendix B.

209 The advertisement consisted of the following: "Need Money? We can help. 5\% interest per month, $60 \%$ annual interest rate."

210 For completeness, it is worth mentioning one condition that was not included: Since 2015 the RLC has recommended that advertisements for high-cost loans include a warning that high-cost loans were not suitable for long-term borrowing. This warning was not tested given its apparent ineffectiveness so far, and to focus more directly on the effect of insulation and debiasing strategies. 
total cost cap. ${ }^{211}$ This cost cap was chosen given its importance to the government. ${ }^{212}$ Also, it was frequently cited in submissions to the FEC and is one of the broadest and easiest to understand restrictions in the 2019 Amendments. ${ }^{213}$

\section{Debiasing conditions}

The four debiasing conditions used are based on the same debiasing strategy, and attempt to counter the optimism bias which affects prospective borrowers' assessment of their ability to repay a high-cost loan. Consider this example of the advertisement:

Figure 1

"Need Money? We can help.

$5 \%$ interest per month, $60 \%$ annual interest rate.

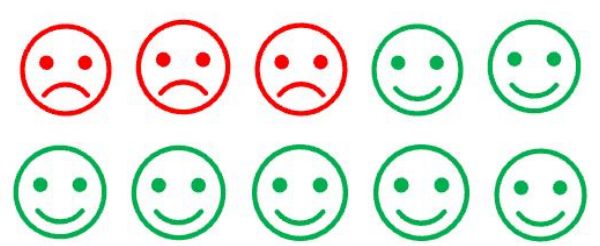

Important Note: For every 10 customers we have, 3 missed payments and end up paying large late fees and increased interest rate charges.

This can be caused by unexpected expenses, such as car or house repairs, or unexpected drops in income, such as losing a job or working fewer hours.

Missed payments can result in severe consequences, such as losing your house, car and other possessions."

211 The advertisement was the same advertisement as in the control condition, followed by: "Important Note: The total amount of interest and fees we charge you can never exceed the original amount of the loan. For example, if you borrow $£ 500$, the most you would pay back is $£ 1000$ ( $£ 500$ for the original loan plus $£ 500$ in interest and fees)." The use of GBP instead of NZD is discussed below.

212 (12 December 2019) 743 NZPD at 15939; (19 November 2019) 743 NZPD at 15239-15240; and (30 April 2019) 737 NZPD at 10574.

213 As recorded by the Ministry of Business, Innovation and Employment, above n 132, at [28]:

65 submitters supported the cap, including Financial Services Complaints Limited, Citizens Advice Bureau New Zealand, Community Law Centres o Aotearoa, the New Zealand Bankers' Association, Cash Converters, Catholic Archdiocese of Wellington, Good Shepherd, Ngā Tāngata Microfinance, Save My Bacon, Whanganui District Council, Josephite Justice Network, KiwiDebt Limited and 39 budget service submissions. 
This advertisement begins with the basic offer and interest rates from the control condition but adds information about the number of borrowers from that lender who have missed payments, possible reasons for missing payments, and the possible negative consequences.

(a) Number of borrowers who have missed payments

The first element of the debiasing strategy is for lenders to disclose the percentage of current customers who have missed payments, drawing from Bar-Gill's emphasis on product-use information over product-attribute information. Most product information currently disclosed falls in the latter category and describes the characteristics or attributes of the product, for example, nutritional information on food or fuel efficiency in automobiles. This is the current situation for New Zealand lending, where the law requires disclosure of attributes, such as the annual interest rate. ${ }^{214}$ However, often the effects of a product, including any harm from it, are just as dependent on how the product is used as compared to the product's attributes. ${ }^{215}$ The harm from high-cost lending is not just due to high interest rates (which are already disclosed under current requirements) but also, and sometimes far more significantly, from borrowers missing payments and accruing unanticipated interest rate charges and penalty fees.

In a perfect world, a potential borrower would be able to accurately assess their own likelihood of missing a payment and incurring additional charges. A useful proxy, given the push nature of advertising, is to show the proportion of the lender's current customers who incur late penalties. The experiment used "smile" and "frown" emoticons to illustrate bad and good outcomes, in this case that 30 per cent of this lender's customers incur additional charges. Research has shown that people "can process information better when it is presented with visual aids as opposed to when it is expressed as numerical probabilities." 216 Further, research has demonstrated that people care more about harm to "identified" people, instead of "statistical" people. ${ }^{217}$ In the absence of actual identified people, the use of "For every 10 customers we have, 3 missed payments" was designed to raise the prospect of those three individuals in the minds of participants more than a generic "30\%" rate would.

A further advantage of this approach is to draw attention to a lender's record and to make the number of its customers who miss payments a salient issue. This is important because a common thread running through the government reports and Hansard for the 2019 Amendments was that many of the issues with harmful lending originated with lenders making loans on terms that were neither affordable nor suitable for the borrower, who would then go on to miss payments and incur additional

214 CCCFA, Schedule 1.

215 Bar-Gill, above n 9, at 13-15.

216 The Money Advice Service A behavioural approach to managing money: Ideas and results from the Financial Capability Lab (Money Advice Service, Behavioural Insights Team and Ipsos MORI, May 2018) at 52; and David Spiegelhalter "Risk and uncertainty communication" (2017) 4(1) Annu Rev Stat Appl 31 at 36-41.

217 Thaler, above n 30, at 13 . 
charges. ${ }^{218}$ If borrowers are reluctant to borrow money from lenders with poor records, and are shown that record prior to borrowing, this would lower demand for loans from those lenders. Eventually lenders with poor records would either be forced to improve their affordability and suitability assessments in order to improve their then-public record, or suffer an erosion in demand. Government mandated disclosure can be a tool to make an issue salient to consumers. ${ }^{219}$

Finally, the above example uses a lender which had 30 per cent of its customers miss payments. For the experiment, we showed participants four advertisements, each of which had a different rate of missing payments. The rates used were 10 per cent, 30 per cent, 50 per cent and 70 per cent to cover a wide range of lender types from the responsible to irresponsible. While historical data is hard to come by, the upper rate of 70 per cent rate was chosen to approximate the highest rate recorded in a survey by the Commerce Commission. ${ }^{220}$

(b) Reasons for missing payments

The second element of the debiasing strategy is to counter the optimism bias by using the availability heuristic, ${ }^{221}$ whereby people's perception of the probability that an event will occur is based on how easily examples come to mind. ${ }^{222}$ This can be further reinforced by the vividness and coherence of the example. Jolls and Sunstein suggest that "making an occurrence available to individuals will increase their estimates of the likelihood of the occurrence," which could help debias those suffering from irrational optimism. ${ }^{223}$ The experiment's debiasing advertisement utilised this by giving specific examples of reasons why a borrower might not be able to make payments on a loan. The advertisement mentions unexpected job loss, car and house repairs, all of which are reasons frequently cited in the FEC submissions for missing loan payments. ${ }^{224}$ The objective is to remind potential borrowers of specific reasons why they might miss a payment; this should counter the innate optimism which leads them to overestimate the probability of making the payments.

218 Ministry of Business, Innovation and Employment, above n 111, at 12 and 20-21.

219 Bar-Gill, above n 9, at 91

220 Commerce Commission, above n 112, at [14].

221 Jolls and Sunstein, above n 4, at 209-210.

222 See Part II above.

223 Jolls and Sunstein, above n 4, at 210 .

224 Budget Advisory Service Inc "Submission to the Finance and Expenditure Select Committee on the Credit Contracts Legislation Amendment Bill" at 5; Christians Against Poverty New Zealand, above n 147, at 8; Christians Against Poverty New Zealand, above n 202, at 2; Christchurch Budget Services Inc, above n 153, at 2.4; M Claire Dale and Erwann Sbai "External Evaluation 2016: A pathway toward financial inclusion and improved wellbeing" (University of Auckland Centre for Applied Research in Economics Working Paper no 1, September 2017) at 17; Compassion Trust "Oral Submission to Finance and Expenditure Select Committee on the Credit Contracts Legislation Amendment Bill" at 6; and CARE Waitakere Trust, above n 154, at 5. 


\section{(c) Consequences}

The final part of the advertisement lists possible consequences for missing payments: the loss of the borrower's house, car and other possessions. While the borrower is presumably aware of the gains from a loan, this forces the borrower to confront possible losses. This taps into the loss aversion bias, where most people fear losses more than they value gains. It also ties into the job loss/unexpected expenses discussed earlier in the advertisement, which forms a coherent narrative: how if you borrow money and lose your job, you could also lose your house. Such a coherent narrative increases the occurrence of that probability in a borrower's mind, thereby counteracting the optimism bias.

\section{Survey Subjects}

The survey was originally designed for New Zealand residents; unfortunately, this approach had to be abandoned due to time restrictions. Instead, experiment participants were sourced from Prolific, an online data collection company that links paid participants with researchers. Using participants from the United Kingdom, it has greater numbers of participants and more rapid response rates. The New Zealand dollar amount in the survey $(\$ 850)$ was converted to the pound equivalent $(£ 450)$. The United Kingdom was chosen as a proxy for New Zealand as it faced similar problems with high-cost loans in the past and had introduced a similar solution. ${ }^{225}$

Participants were screened by Prolific on the basis of annual household income being under $£ 20,000$ (approximately $\$ 40,000$ New Zealand dollars). This was estimated as the approximate target demographic for high-cost lending. The study used 100 participants, split evenly between the Necessity and Family Obligation scenarios. Each participant was shown all six experimental conditions randomly, and after each condition, was asked to evaluate the likelihood that they would take out a loan under that condition. Subjects indicated this with radio buttons on a seven-point Likert scale, which included numbers (one to seven) for each button and a description at the end points ("Would not borrow at all" to "Would be sure to borrow"). ${ }^{226}$

\section{RESULTS}

Following a pilot trial of five subjects, the experiment was refined and then run for 100 participants, evenly split between the Necessity and Family Obligation scenarios. Each participant self-reported

225 As per university rules, ethics approval for this experiment was given by the Human Ethics Committee prior to any interaction with subjects (reference 0000028912, 13 September 2020).

226 Rensis Likert "A Technique for the Measurement of Attitudes" (1932) 22(140) Archives of Psychology 5 at $15-20$. 
the likelihood of borrowing under the six experimental conditions above. ${ }^{227}$ The overall results were as follows:

Figure 2

\begin{tabular}{|l|l|c|c|}
\hline Scenario & Condition & Mean & Standard error \\
\hline Necessity & Control & 3.10 & 0.24 \\
\hline & Current Law & 3.02 & 0.28 \\
\hline & Debiasing 10 & 2.68 & 0.25 \\
\hline & Debiasing 30 & 2.52 & 0.23 \\
\hline & Debiasing 50 & 2.40 & 0.21 \\
\hline & Debiasing 70 & 2.02 & 0.19 \\
\hline Family Obligation & Control & 2.14 & 0.23 \\
\hline & Current Law & 2.66 & 0.27 \\
\hline & Debiasing 10 & 2.78 & 0.31 \\
\hline & Debiasing 30 & 2.32 & 0.26 \\
\hline & Debiasing 50 & 1.88 & 0.22 \\
\hline & Debiasing 70 & 1.48 & 0.16 \\
\hline
\end{tabular}

Figure 3
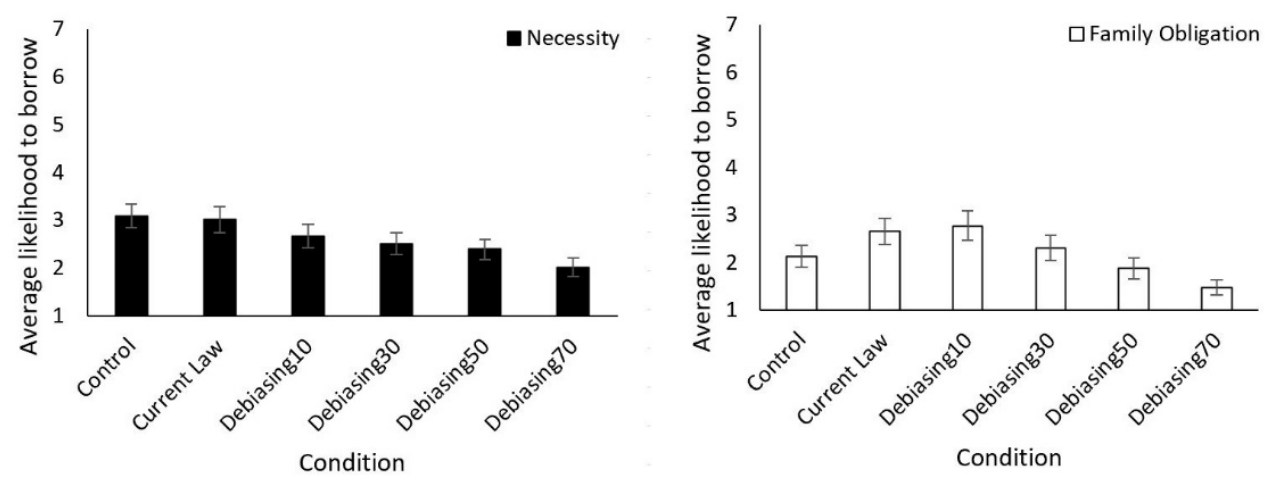

The data was used to test three things: First, the Control condition of basic interest information was compared to the effect of the current law which requires borrowers to be informed of the total cost cap in addition to basic interest rate information. Secondly, the effect of the debiasing conditions

227 The four debiasing conditions are indicated by "Debiasing" followed by the percentage of the lender's customers who had previously missed payments. For example, the condition where the lender had a 30 per cent missed payment rate is represented by "Debiasing30". 
was compared to the Control. Thirdly, the data was used to test whether increasing the lender's percentage of missed payments in the debiasing conditions (informing borrowers that a lender has a greater percentage of customers missing payments) increases the effect of the debiasing. These will be discussed in turn, followed by a discussion of the policy implications.

\section{A Current Law Compared to Control}

A factorial two-way Analysis of Variance (ANOVA) was used to test the effects of changing both the experimental condition (Current Law vs Control) as well as the scenario (Necessity vs Family Obligation). ${ }^{228}$ Testing generated a significant interaction between changing condition and scenario $(F(1,98)=4.69, p=.033)$, suggesting that their effect on likelihood to borrow depends on the specific combination of the two. The $\mathrm{P}$ value is the probability that the there is no effect, and a $\mathrm{P}$ value of less than five per cent $(p<.05)$ is commonly considered to indicate significance (that there is an effect). This interaction can be usefully broken down by scenario. In the Necessity scenario, there was no difference $(p=.977)$ in the likelihood to borrow between the Control (mean $=3.10)$ and the Current Law (mean $=3.02$ ) conditions. In the Family Obligation scenario, however, there was a significant difference $(p=.045)$ between the Control (mean $=2.14)$ and the Current Law (mean $=2.66$ ). Participants in the Family Obligation scenario were more likely to borrow when told of the total cap on repayments, in comparison to the control condition.

Figure 4

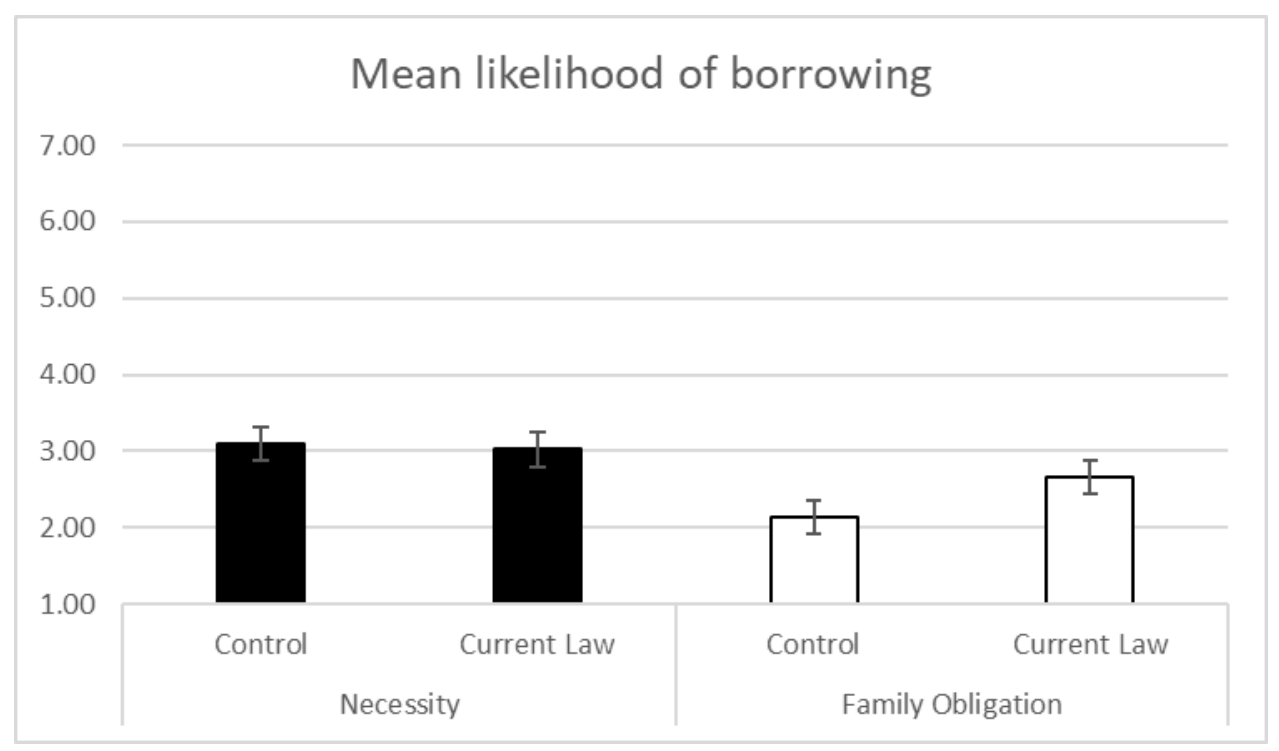

228 The ANOVA results (F statistic, $\mathrm{P}$ values) were generated by Rana Asgarova, a senior tutor in the VUW psychology department. The application, and any mistakes, are the author's. 


\section{B Debiasing Conditions Compared to Control}

For this comparison, a repeated-measures ANOVA was conducted for each scenario to examine (within that scenario) each debiasing condition against the Control. ${ }^{229}$ For the Necessity scenario, there was a significant interaction among the conditions $(F(4,196)=11.90, p<.001)$ where Debiasing $30($ mean $=2.52, p=.004), 50$ (mean $=2.40, p<.001)$ and $70($ mean $=2.02, p<.001)$ were significantly different from the Control (mean $=3.10)$. No significant difference from the control was seen for Debiasing 10 (mean $=2.68, p=.075)$. This indicates that when shown debiasing strategies with lenders who had 30 per cent, 50 per cent and 70 per cent missed payment rates, participants were significantly less likely to borrow money.

Figure 5

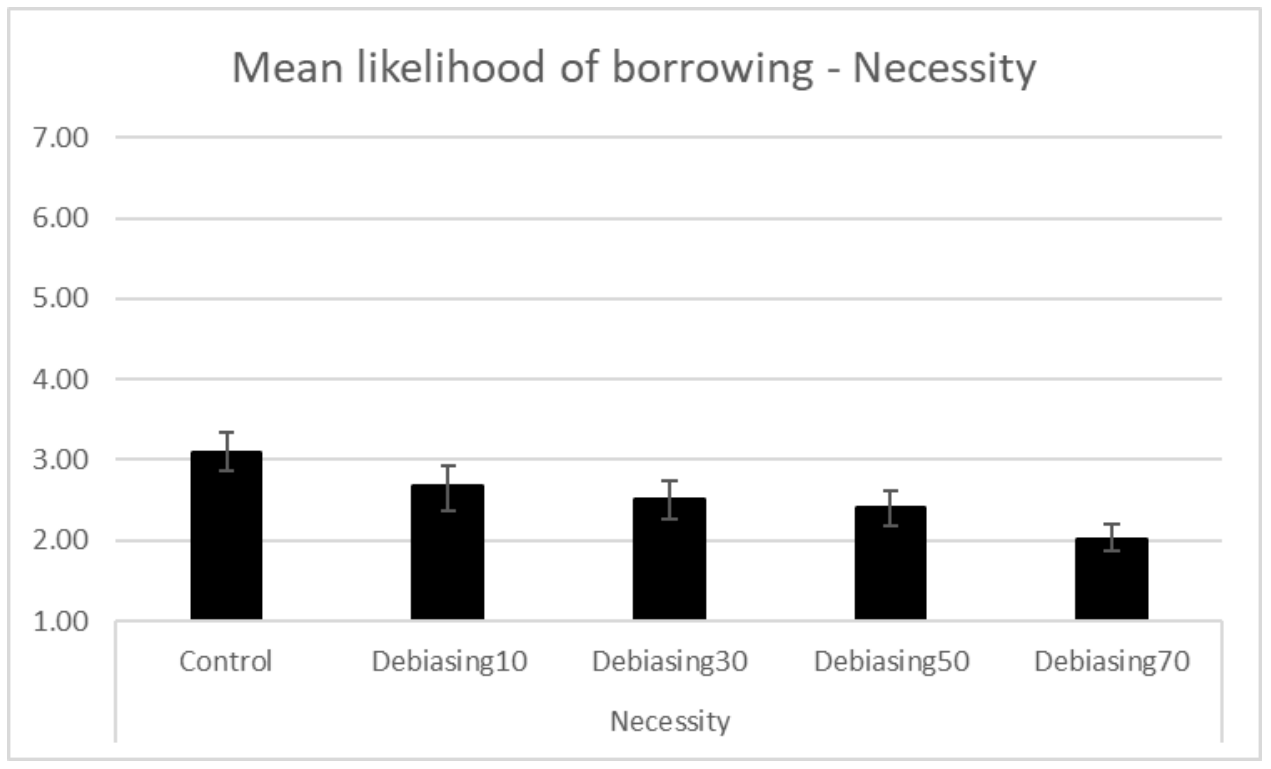

A different result was seen in the Family Obligation scenario. There was a significant difference among the conditions $(F(4,196)=17.83, p<.001)$. First, Debiasing $10($ mean $=2.78, p=.001)$ showed a significant difference compared to the Control (mean $=2.14$ ). This shows that participants were more likely to borrow money from a lender with a 10 per cent missed payment rate, compared to the Control. The second condition that showed a significant difference from the Control was Debiasing 70 (mean $=1.48, p<.001)$. Compared to the Control, participants were significantly less likely to borrow money when shown a lender with a 70 per cent missed payment rate. There was no significant

229 The ANOVA results (F statistic, P values) were generated by Rana Asgarova, a senior tutor in the VUW psychology department. The application, and any mistakes, are the author's. 
difference from Control for either Debiasing 30 (mean $=2.32, p=.803)$ or Debiasing 50 (mean $=$ $1.88, p=.500)$.

Figure 6

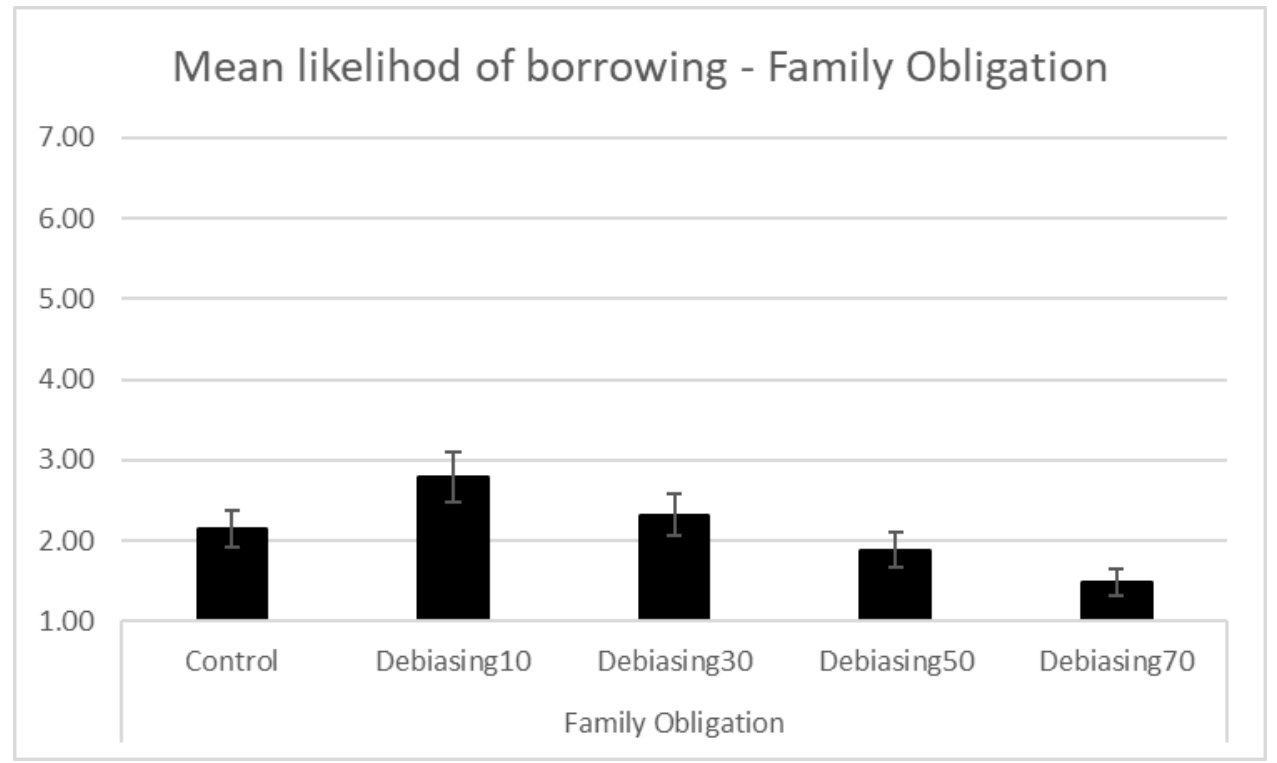

\section{Linearity of Debiasing Strategies}

The experiment tested for one other effect: whether increasing the lender's percentage of customers missing payments progressively decreased the likelihood that the participant would borrow from that lender. ${ }^{230}$ For example, would participants be less likely to borrow at Debiasing 30 than at Debiasing 10, less likely to borrow at Debiasing 50 than Debiasing 30? This was tested by a repeated measures ANOVA, which showed a significant effect of changing the missed payment rate on the debiasing conditions in both Necessity $(F(1.90,92.92)=7.09, p=.002)$ and Family Obligation $(F(1.79,87.91)=22.08, p<.001)$ scenarios. Further inspection showed that this change produced a linear response in likelihood to borrow in both Necessity $(F(1,49)=9.68, p=.003)$ and Family Obligation $(F(1,49)=30.78, p<.001)$. In other words, changing the missing payment percentages does impact the likelihood of borrowing, and in a linear fashion, with higher lender missed payment rates resulting in a lower likelihood of borrowing from the participants.

230 The ANOVA results (F statistic, $\mathrm{P}$ values) were generated by Rana Asgarova, a senior tutor in the VUW psychology department. The application, and any mistakes, are the author's. 
Figure 7

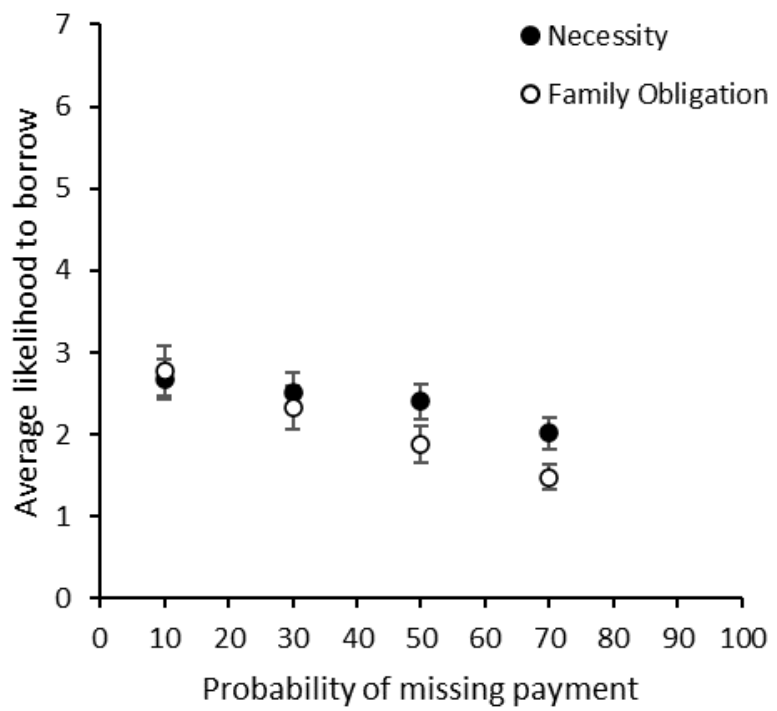

\section{POLICY IMPLICATIONS}

These results may be used to refine consumer credit policy to improve its effectiveness and to better achieve its intended goals. First, the experiment suggests that the insulation strategy of the 2019 Amendments might have the perverse effect of increasing borrowing. The cap on total cost appears to increase the chances that consumers take out loans, at least for certain purposes, such as family obligations. This unintended consequence should be included in the review of the high-cost loans restrictions mandated by the CCCFA to occur in three years as any growth in high-cost loans could increase harm. ${ }^{231}$

Secondly, debiasing strategies, the effectiveness of which were demonstrated in the experiments, should be used to counter the optimism bias and decrease irrational demand for high-cost loans. Reminding potential borrowers of the costs of missing payments, reasons why that might happen and the consequences that could result appears to lower the likelihood they will take out the loan, at least in certain circumstances. These debiasing strategies could be incorporated into the advertising standards regulations introduced to the RLC by the 2019 Amendments. ${ }^{232}$ Mandated warnings about product use, as outlined above, would aid in harm reduction of high-cost loans.

231 CCCFA, s 45L. This requires a review of Subpart 6A, which encompasses many of the high-cost loan restrictions, including the total cost cap: see s $45 \mathrm{E}$.

232 Sections 9C(3)(b)(i)(A), 9F(1)(b)(i) and 138(1)(abc). 
A third key finding is the importance of lender disclosure of missed repayment rates in informing consumer borrowing decisions. The experiment shows that consumers are increasingly less likely to borrow when they see that lenders have higher rates of customers with missed payments. As such, requiring New Zealand high-cost lenders to make such disclosures would drive borrowers away from lenders with flawed affordability and suitability assessments and towards more responsible ones. Lenders would then have to compete on their ability to offer suitable and affordable loans.

Improving disclosures, as outlined in the preceding paragraph, is a possible alternative to increasing regulations. Recent legislative developments in consumer lending have focused on tightening regulations around lenders' affordability analyses of borrowers, including prescriptive requirements. Such prescriptions have the potential to be expensive, intrusive and static, especially in an industry undergoing rapid technological change. ${ }^{233}$ Mandating the disclosure of customer missed payment rates is an alternative approach that encourages more responsible lending while maintaining lender flexibility. Implementation costs would be low, as the 2019 Amendments already require lenders to supply annual returns and other statistical data, including loan books, to the Commerce Commission; it is a short step to then provide relevant information to the public. ${ }^{234}$

The experiment conducted for this article is proof of the concept, albeit on a small scale, that debiasing can reduce the likelihood, and therefore harm, of high-cost borrowing. While it is effective, debiasing is unlikely to reduce harm as thoroughly as insulation. Because a steep reduction in harm was Parliament's intent, insulation has been widely accepted by Parliament and is now part of the New Zealand legal landscape. Insulation is expected to be further entrenched given that the Labour Party now has a majority in the legislature. However, insulation is a blunt tool that indiscriminately affects all borrowers and lenders, even those who may mutually benefit from high-cost lending, and eliminates products regardless of whether they address a valid market need. To retain the benefits that high-cost lending could offer whilst alleviating the potential harm, a more nuanced policy approach is necessary.

In this respect, debiasing could potentially be used in tandem with insulation to soften or replace some of the more onerous insulating strategies of the 2019 Amendments. For example, the most controversial part of the 2019 Amendments is the daily interest rate cap. ${ }^{235}$ Providers of short-term credit highlight that the cost structure of short-term credit, with high fixed costs and few days to collect interest, made short-term lending uneconomic under the daily cap. ${ }^{236}$ Already, some have left the market. Increasing or eliminating that cap, combined with mandatory debiasing messages, could still

233 Ministry of Business, Innovation and Employment, above n 108, at 13-16.

2342019 Amendments, s 47: which inserted s 116AAA into the CCCFA.

235 (12 December 2019) 743 NZPD at 15941.

236 The maximum amount a lender can charge on $\$ 100$ loaned for five days would be $\$ 4$, to cover all of the lender's fixed and origination costs. 
reduce harm while lowering market distortion and giving consumers access to a wider and more flexible range of financial products. As such, debiasing, when coupled with a pared down insulation approach, can be a powerful tool to achieve the government's objectives in the consumer credit industry. 


\section{Appendix A}

\section{Scenarios (New Zealand design)}

Necessity:

Please consider this scenario before answering the questions on this page. Scenarios will change slightly from page to page.

It has been quite some time since you have paid your power bill, and now owe $\$ 850$. You have received a 'Final Notice' from the power company, which threatens to turn off the power. You do not have the money to pay the bill, and in the past you have struggled to borrow money from normal banks due to your bad credit score. You also feel uncomfortable borrowing money from friends and family. You hear about a company that lends money more easily than normal banks, but charges a high interest rate. Their website and other advertising show the following:

Family Obligation:

Please consider this scenario before answering the questions on this page. Scenarios will change slightly from page to page.

A family member is having a wedding, and you would like to go. The trip will cost $\$ 850$. You do not have the money to pay for the trip, and in the past you have struggled to borrow money from normal banks due to your bad credit score. You also feel uncomfortable borrowing money from friends and family. You hear about a company that lends money more easily than normal banks, but charges a high interest rate. Their website and other advertising show the following:

\section{Scenarios (UK design)}

Necessity:

Please consider this scenario before answering the questions on this page. Scenarios will change slightly from page to page.

It has been quite some time since you have paid your power bill, and now owe $£ 450$. You have received a 'Final Notice' from the power company, which threatens to turn off the power. You do not have the money to pay the bill, and in the past you have struggled to borrow money from normal banks due to your bad credit score. You also feel uncomfortable borrowing money from friends and family. You hear about a company that lends money more easily than normal banks, but charges a high interest rate. Their website and other advertising show the following: 
Family Obligation:

Please consider this scenario before answering the questions on this page. Scenarios will change slightly from page to page.

A family member is having a wedding, and you would like to go. The trip will cost $£ 450$. You do not have the money to pay for the trip, and in the past you have struggled to borrow money from normal banks due to your bad credit score. You also feel uncomfortable borrowing money from friends and family. You hear about a company that lends money more easily than normal banks, but charges a high interest rate. Their website and other advertising show the following:

\section{Appendix B}

1 Control Condition

"Need Money? We can help.

$5 \%$ interest per month, $60 \%$ annual interest rate."

Current Law Condition

"Need Money? We can help.

$5 \%$ interest per month, $60 \%$ annual interest rate.

Important Note: The total amount of interest and fees we charge you can never exceed the original amount of the loan. For example, if you borrow $£ 500$, the most you would pay back is $£ 1000$ ( $£ 500$ for the original loan plus $£ 500$ in interest and fees)."

3 Debiasing Condition (this example is $30 \%$ of customers with missed payments)

"Need Money? We can help.

$5 \%$ interest per month, $60 \%$ annual interest rate."

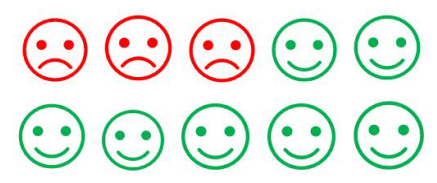

Important Note: For every 10 customers we have, 3 missed payments and end up paying large late fees and increased interest rate charges.

This can be caused by unexpected expenses, such as car or house repairs, or unexpected drops in income, such as losing a job or working fewer hours.

Missed payments can result in severe consequences,

such as losing your house, car and other possessions. " 
